Open Access

Research Article
Res. Agric. Livest. Fish.

Vol. 2, No. 2, August 2015: 239-246

\title{
WOMEN LABOR PARTICIPATION IN RICE PRODUCTION IN SOME SELECTED AREAS OF THAKURGAON DISTRICT
}

\author{
Asha Roy ${ }^{1 *}$, Dilshad Zahan Ethen ${ }^{2}$, Riffat Ara Zannat Tama ${ }^{1}$ and Ismat Ara Begum ${ }^{1}$ \\ ${ }^{1}$ Department of Agricultural Economics, Bangladesh Agricultural University, Mymensingh- \\ 2202, Bangladesh; ${ }^{2}$ Department of Agribusiness and Marketing, Bangladesh Agricultural \\ University, Mymensingh- 2202, Bangladesh
}

*Corresponding author: Asha Roy, E-mail: ashatheroy@gmail.com

\section{ARTICLE INFO}

ABSTRACT

Received

05.08.2015

Accepted

30.08.2015

Online

03.09.2015

Key words

Women labor

participation,

Rice production,

Household

expenditure,

Rural society
The present study was undertaken to analyze the participation of women labor in rice production activities covering randomly selected 50 rural households of two villages under Ranisonkail Upazila of Thakurgaon district. Data were collected from the selected households using face to face semi-structured interviews during December 2013 to February 2014. The study revealed that in rice production activities the percentage of hiring out days for women were 94.18 and 92.90 in aman and boro seasons, respectively. To determine the effects of the explanatory variables on women labor participation in rice production, Ordinary Least Square method was used. The analysis showed that age of the respondents and total household expenditure were positively related with women participation but negatively related with education, number of male earning members and farm size of the households. The study concludes that education, credit facilities, extension and motivation, need-based training should have the potential to increase women's participation in farm activities reasonably contributed to household income. Therefore, effective initiatives undertaken by the concerned agencies in improving women's education, skill acquisition training and access to information could enhance women's empowerment in order to achieve gender equality and development at all levels in the rural society of Bangladesh.

To cite this article: A Roy, DZ Ethen, RAZ Tama and IA Begum, 2015. Women labor participation in rice production in some selected areas of Thakurgaon district. Res. Agric. Livest. Fish. 2 (2): 239-246.

This is an open access article licensed under the terms of the Creative Commons Attribution 4.0 International License

www.agroaid-bd.org/ralf, E-mail: editor.ralf@gmail.com 


\section{INTRODUCTION}

Traditionally the status of women in Bangladesh is domestic in nature. Women have been considered as a docile daughter, a complacent wife and a dependent mother. They are more obliged to abide by all manners of cultural, social and economic origin than men. They typically work longer hours with a lower wage. Their household work is not considered as an economic activity although they are contributing $54 \%$ to $60 \%$ of total work time ((ILO, 2009). Situation of rural women in Bangladesh presents a dismal picture. Rural women's primary asset is their own labor therefore one of the keys to achieving the Millennium Development Goals (MDGs), is to ensure more and better rural employment whether waged or self-employed enterprise (Fontana and paicello, 2010). Lack of access to decent work is a major cause of poverty among rural people and particularly rural women (ILO, 2009). The total labor force in the country is 54.1 million of which 37.9 million (70\%) are males and 16.2 million (29.95\%) are females (BBS, 2012). This is shown in Table 1.

The women of Bangladesh are very much involved in farm activities. Women's agricultural activities are confined to homestead production and post-harvest operations. A number of studies were conducted on women's activities during 1980s (Abdullah and Zeidenstein, 1982; Chakma, 1995; Farzana, 2004; Jaim and Rahman, 1988). These studies found that women's contribution to socio-economic development was not visible, perhaps due to a set of social norms that enabled men to dominate women (Bose, et. al., 2009).

As an agro-based country, like Bangladesh most of the people are dependent on agriculture. About $80 \%$ (BBS, 2010) of total population is engaged in agricultural sector especially in rice production for their livelihood. Rice is the staple food of the people and about 10.67 million ha of land (about $80 \%$ of the cropped area) is used for rice cultivation and growing 24.29 million metric tons (BBS, 2002). Agriculture is about all activities relating to agricultural input, provision, farming and the processing and distribution activities that add value to farm products. It provides for two basic human needs, namely food and fiber and strong economic and employment linkages with other sectors of the economy thus contributing substantially to economic growth of a country. There has been scarcity of rural agricultural labor force in recent years and farm technologies have not yet sufficiently developed to cope with this scarcity. Therefore, women participation, particularly in rice production is increasing in Bangladesh. The progress is attributed to poverty, empowerment of women by NGOs, and migration of male members from agriculture to non-farm occupation. The agricultural labor force in Bangladesh is shown in Table 2. Female labor participation in agriculture compared to male increased over time. During the period from 1999-2000 to 2005-2006, there had been absolute decrease in male labor force which was 16.2 million to 15.1 million during the period from 1999-2000 to 2005-2006, a decrease by about $7 \%$. On the other hand, during the same period, female labor has increased from 3.8 million to 7.7 million, an increase by about 103\% (Table 2). FAO has noted that while the overall proportion of the economically active population (EAP) working in agriculture declined during the 1990s, the percentage of economically active women working in agriculture at the global level remained nearly 50 percent through 2000, with an even higher percentage in developing countries (61\%) and in LDCs (79 \%) FAO (2003).

In Bangladesh, being a traditional Muslim society, women in Bangladesh hardly participate in agricultural activities outside home (Abdullah and Zeidenstein, 1982). Women's agricultural activities were confined to homestead production and post-harvest operations; however, in recent years they are mostly involved in livestock and poultry rearing activities besides crop. In terms of research very few studies pertaining to women participation in agricultural activities have been carried out. Keeping in view the dearth of information concerning women participation in agricultural activities, the study in hand is initiated to fill these gaps. With the above background, the present study aims at:

a. To analyze the nature and extent of women labor participation in rice production activities.

b. To analyze the factor influencing women participation in rice production activities.

c. To suggest some policy recommendations based on the findings.

\section{MATERIALS AND METHODS}

The study was carried out during December 2013 to February 2014 in two villages namely Bhangbari and Bachor under Ranisonkail Upazila of Thakurgaon district. Taking into account the objectives, time and availability of fund and man power, two villages were selected purposively and a sample of 50 women labor was chosen by using random sampling technique. Data were collected from primary sources and its collection 
was accomplished by direct interviews with the selected respondents. Considering the objectives of the study, a number of relevant tables were prepared. Finally tabulated data were analyzed using simple statistical techniques such as mean, percentage, ratio etc. Data entry was made in the computer and analysis was done using the Microsoft Excel and STATA. Both tabular and functional analyses were adopted in the study. Functional analysis was carried out to focus on the factors that influenced the level of women participation.

\section{Functional Analysis}

Ordinary least square (OLS) method was used to determine the relationship between women participation in rice production activities and a few selected but relevant variables with a view to identify factors that would have significant impact on women participation. Participation of women in rice production activities as dependent variable $\left(Y_{i}\right)$ while five independent variables were considered as can be seen from the following equation. Women participation in rice production activities was measured in man-days/year and one day consists of 8 hours.

$Y_{i}=f\left(X_{1}, X_{2}, X_{3}, X_{4}, X_{5}\right)$

$\mathrm{Y}=$ Participation of women in rice production activities (man-day/ year)

$\mathrm{X}_{1}=$ Age of respondent (year)

$\mathrm{X}_{2}=$ Educational level of the respondent (Dummy; if literate then $\mathrm{Di}=1$ or $0=$ otherwise)

$X_{3}=$ Number of male earning members in household (No.)

$\mathrm{X}_{4}=$ Farm size of the household (acre)

$\mathrm{X}_{5}=$ Total household expenditure (Tk. per annum)

\section{RESULT AND DISCUSSION}

Nature and extent of women participation and rice production activities

In the study area, rice is produced in two seasons, aman and boro seasons. It was found that women were mostly involved in transplanting, weeding and post-harvest operation like harvesting, carrying, threshing, drying, storage etc. Table 3 shows the participation of male and female labor in different operations during rice production. It can be seen from Table 3 that male labor participated in all kinds of activities in rice production but female labor participated mostly in post-harvest operation.

Considering 8 working hours per day, women labor contributed 114.08 days of which aman and boro production activities consisted of 56.23 days and 57.85 days respectively (Table 4). In rice production the percentage of hiring out days for women were found to be 94.18 and 92.90 percent in aman and boro seasons, respectively.

Table 1. Female Labor Force in Bangladesh

\begin{tabular}{lllllll}
\hline Year & \multicolumn{3}{c}{ Labor force (million) } & \multicolumn{3}{c}{ \% of total labor force } \\
\cline { 2 - 7 } & National & Urban & Rural & National & Urban & Rural \\
\cline { 2 - 6 } 1981 & 1.5 & 0.2 & 1.3 & 5.7 & 6.0 & 5.7 \\
$1983-84$ & 2.5 & 0.4 & 2.1 & 8.9 & 10.5 & 8.6 \\
$1984-85$ & 2.7 & 0.5 & 2.2 & 9.0 & 10.5 & 8.6 \\
$1985-86$ & 3.2 & 0.6 & 2.6 & 10.4 & 13.4 & 9.9 \\
1989 & 21.0 & 1.5 & 19.5 & 41.4 & 26.3 & 43.2 \\
$1990-91$ & 20.1 & 2.1 & 18.0 & 39.3 & 24.1 & 42.4 \\
$1995-96$ & 21.3 & 2.8 & 18.5 & 38.0 & 5.0 & 33.0 \\
$1999-2000$ & 8.6 & 2.2 & 6.4 & 21.1 & 5.4 & 15.7 \\
$2002-03$ & 10.3 & 2.7 & 7.6 & 22.2 & 5.8 & 16.4 \\
$2005-06$ & 12.1 & 2.8 & 9.3 & 24.4 & 23.9 & 24.6 \\
2010 & 17.2 & 4.0 & 13.2 & 29.6 & 29.3 & 29.7 \\
\hline
\end{tabular}

Source: BBS, 2012 
Table 2. Agricultural Labor Force in Bangladesh

\begin{tabular}{llll}
\hline Periods & Total labor force (million) & Male (million) & Female (million) \\
\hline $1995-96$ to $1999-00$ & 20 & 16.2() & 3.8 \\
$1999-00$ to $2002-03$ & 23 & 17.2 & 5.8 \\
$2002-03$ to $2005-06$ & 22.9 & 15.1 & 7.8 \\
\hline
\end{tabular}

Source: BBS (2004) and BBS (2008).

Table 3. Operation Wise Male and Female Participation in Rice Production

\begin{tabular}{|c|c|c|}
\hline Operations & Male & Female \\
\hline Land preparation & $\star \star \star$ & * \\
\hline Transplanting & 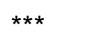 & $\star \star \star ~$ \\
\hline Weeding & $\star \star \star$ & ** \\
\hline Irrigation & 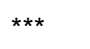 & * \\
\hline Fertilizing & $\star \star \star \star ~$ & * \\
\hline Harvesting & $\star * \star$ & $\star \star \star \star ~$ \\
\hline Carrying & $\star \star \star \star ~$ & $\star \star \star *$ \\
\hline Threshing & 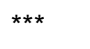 & $\star \star \star *$ \\
\hline Cleaning & $\star \star \star \star ~$ & * \\
\hline Drying & $\star \star$ & 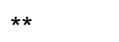 \\
\hline
\end{tabular}

Source: Review of literature

Note: *** indicate large participation; ** indicate medium participation and *indicate small participation

Distribution of operation wise women labor participation in aman production is shown in the Table 5. In aman season, female labor worked 14.99 days for transplanting, 10.88 days for weeding, 12.39 days for harvesting, 7.99 days for carrying, 9.8 days for threshing and 0.18 days for drying. The highest percentage was found in transplanting (26.66\%) and lowest percentage was found in drying $(0.32 \%)$.

Table 6 shows operation wise participation of female labor in boro season. In boro season irrigation is most important operation. But it was found that in the study area usually women were not engaged in irrigation. Male labors are more efficient than women in irrigation. In boro season women worked 14.15 days for transplanting, 11.28 days for weeding, 12.49 days for harvesting, 7.85 days for carrying, 9.68 days for threshing and 2.4 days for drying. So the highest percentage of participation was found in transplanting and lowest was found in drying also.

Table 4. Participation of Women in Rice Production Activities by all Households (Average No. of Days per Year)

\begin{tabular}{llll}
\hline \multirow{2}{*}{ Rice Production } & Particulars & \multicolumn{2}{c}{ Women Participation } \\
\cline { 3 - 4 } & & No. of days & \% of total \\
\hline Aman Production & Family labor & 3.27 & 5.82 \\
& Hired by others & 52.96 & 94.18 \\
\multirow{3}{*}{ Boro Production } & Total & 56.23 & 100 \\
& Family labor & 4.11 & 7.10 \\
\multirow{2}{*}{ Total } & Hired by others & 53.74 & 92.90 \\
& Total & 57.85 & 100 \\
& Family labor & 7.38 & 6.47 \\
& Hired by others & 106.7 & 93.53 \\
\hline
\end{tabular}

Source: Field Survey, 2014 
Table 5. Operation Wise Women Labor Employment in Aman Season

\begin{tabular}{lcccccc}
\hline \multirow{2}{*}{ Operation } & \multicolumn{3}{c}{ Female labor } & \multicolumn{2}{c}{ All household } \\
\cline { 2 - 7 } & \multicolumn{2}{c}{ Family labor } & \multicolumn{2}{c}{ Hired labor } & \multicolumn{2}{c}{ Total labor } \\
\cline { 2 - 7 } & No. of days & \% of total & No. of days & \% of total & No. of days & \% of total \\
\hline Transplanting & 0.75 & 22.94 & 14.24 & 26.89 & 14.99 & 26.66 \\
Weeding & 0.6 & 18.35 & 10.28 & 19.41 & 10.88 & 19.35 \\
Harvesting & 0.73 & 22.32 & 11.66 & 22.02 & 12.39 & 22.03 \\
Carrying & 0.49 & 14.98 & 7.5 & 14.16 & 7.99 & 14.21 \\
Threshing & 0.62 & 18.96 & 9.18 & 17.33 & 9.8 & 17.43 \\
Drying & 0.08 & 2.45 & 0.1 & 0.19 & 0.18 & 0.32 \\
Total & 3.27 & 100 & 52.96 & 100 & 56.23 & 100 \\
\hline
\end{tabular}

Source: Field Survey

Table 6. Operation Wise Women Labor Employment in Boro Season

\begin{tabular}{lcccccc}
\hline \multirow{2}{*}{ Operation } & \multicolumn{4}{c}{ Female labor } & \multicolumn{2}{c}{ All household } \\
\cline { 2 - 6 } & \multicolumn{2}{c}{ Family labor } & \multicolumn{2}{c}{ Hired labor } & \multicolumn{2}{c}{ Total labor } \\
\cline { 2 - 6 } Transplanting & No. of days & \% of total & No. of days & \% of total & No. of days & $\%$ of total \\
\cline { 2 - 7 } Weeding & 0.75 & 18.25 & 13.4 & 24.94 & 14.15 & 24.46 \\
Harvesting & 0.58 & 14.11 & 10.7 & 19.91 & 11.28 & 19.50 \\
Carrying & 0.77 & 18.74 & 11.72 & 21.81 & 12.49 & 21.59 \\
Threshing & 0.47 & 11.43 & 7.38 & 13.73 & 7.85 & 13.57 \\
Drying & 0.64 & 15.57 & 9.04 & 16.82 & 9.68 & 16.73 \\
Total & 0.9 & 21.90 & 1.5 & 2.79 & 2.4 & 4.15 \\
\hline
\end{tabular}

Source: Field Survey 2014

Factors affecting level of women participation

Ordinary Least Square (OLS), linear and log linear models were initially estimated for determining the effects of some selected factors on the participation of women. But Ordinary Least Square model was better in terms of expected signs and magnitudes of the co-efficient, $\mathrm{R}^{2}$ (adjusted) and F-values. So, the parameter estimators obtained from the OLS. Many factors may affect the participation of women in rice production but it is not proper to include all the variables in a model due to theoretical and economic considerations. Care was also taken to avoid the multicollinearity of the selected variables. 
Effects of selected factors on women participation in rice production

The estimated values of the regression coefficients and related statistics are presented in Table 7.

Table 7. Estimated Values of Co-efficient and Related Statistics

\begin{tabular}{lll}
\hline Selected Variables & Co-efficient & t-value \\
\hline Intercept & 78.87 & 3.06 \\
Age of the respondent $\left(X_{1}\right)$ & $0.99^{\star \star}$ & 2.03 \\
Educational level of respondent $\left(X_{2}\right)$ & -13.37 & -1.53 \\
No. of male earning members $\left(X_{3}\right)$ & $-11.11^{\star \star \star}$ & -1.77 \\
Farm size of the household $\left(X_{4}\right)$ & $-0.305^{\star \star}$ & -2.89 \\
Total Household expenditure $\left(X_{5}\right)$ & 0.0003 & 1.00 \\
$\mathrm{R}^{2}$ & 0.491 & \\
Adjusted $\mathrm{R}^{2}$ & 0.411 & \\
F-value & $3.65^{\star \star}$ & \\
\hline
\end{tabular}

Source: Field Survey 2014

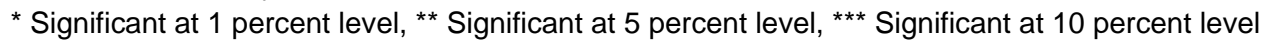

\section{Age of the Respondents $\left(X_{1}\right)$}

Age $\left(X_{1}\right)$ has positive and significant effect on women participation. The regression co-efficient of age was 0.99 which is positive and significant at $5 \%$ level. It means that holding other variables constant if there is an increase of one year in the age of woman, her participation in rice production activities increases by 0.99 manday. Khan et al. (2012) also found the similar result.

\section{Educational Level of Respondent $\left(\mathrm{X}_{2}\right)$}

The regression coefficient of educational level $\left(X_{2}\right)$ was negative and insignificant. So there is a negative relationship between educational level of respondent and their participation. It indicates that most of the respondents were illiterate. Because the higher the level of education the lower the degree of interest to participate in farming activities. The similar result was found by Khan et al. (2012)

\section{No. of Male Earning Members $\left(\mathrm{X}_{3}\right)$}

The estimated regression co-efficient of male earning members $\left(X_{3}\right)$ was negative but significant. It means that keeping other factors constant if the number of male earning increases by a unit then the women participation decreases by 11.11 manday. Khan et al. (2012) also found that there was a negative relationship between number of male earning members and women participation.

\section{Farm Size of the Household $\left(\mathrm{X}_{4}\right)$}

Farm size $\left(\mathrm{X}_{4}\right)$ had negative as well as significant effect on women participation in rice production. It means if farm size is increased by 1 acre then women participation will be decreased by 0.305 man-day. It indicates that women of landless and marginal farm household were involved more in rice production.

\section{Total Household Expenditure ( $\left.X_{5}\right)$}

The estimated co-efficient of total household expenditure $\left(X_{5}\right)$ was 0.0003 , which is positive but insignificant. It means that total household expenditure had no significant impact on women participation in rice production. 


\section{Value of $\mathbf{R}^{2}$ and Adjusted $\mathbf{R}^{2}$}

The estimated coefficient of multiple determination $\left(R^{2}\right)$ was 0.491 , which implies that about 49.1 percent of the total variation in women participation was explained by the set of explanatory variables included in the model. The value of adjusted $\mathrm{R}^{2}$ was 0.411 . It indicates that after taking into account the degrees of freedom (d.f.), the five explanatory variables included in the model still explained about 41.1 percent of the variation in the dependent variable (women participation).

\section{F-value}

The F-value stood at 3.65. It was significant at $5 \%$ level. It measures the overall goodness of fit of the estimated regression model.

\section{CONCLUSIONS AND RECOMMENDATIONS}

Agriculture is the dominant sector in the economy of Bangladesh. The overall development of economy depends largely on the proper utilization of human labor in addition to other factors of production. In Bangladesh women constitute nearly half of the total labor force of the country. The analysis shows that women play an important role in rice production activities especially in transplanting, weeding and postharvest operations. In terms of man-days, the participation of women labor in rice production was remarkable in the study areas. Economic pressure is forcing them to break away their traditional roles of housewives into farm labors. The finding of the present study reveals that contribution of female labor in rice production activities as well as in total family income was substantial. In order to improve the overall economic condition of women labors, the following specific recommendations are suggested.

I. Various agricultural and non-agricultural training along with credit facilities should be offered to the rural women to improve and utilize their skill and efficiency.

II. The potentials of women must be tapped for the socio-economic improvement of the families and development of the nation as a whole

III. Almost all problems faced by the women labor such as discrimination in wages of male and female, poor working environment should be checked through the intervention by the Government and Nongovernment Organizations.

IV. Women are involved in rice production activities. They should be careful about their health and nutrition particularly in pregnancy periods

\section{ACKNOWLEDGEMENT}

This research was supported by the special grants of the Ministry of Science and Technology, Bangladesh, SI No. of grant 154 [Memo No. No.39.012.002.01.03.019.2013-283(459)]

\section{REFERENCES}

1. AbdullahT and S Zeidenstein, 1982. Village women in Bangladesh: Prospects for change. A study prepared for the International Labor Office within the framework of the World Employment Program. Oxford press.

2. BBS (Bangladesh Bureau of Statistics), 2002. Statistical Yearbook for Bangladesh., Statistics Division, Ministry of Planning, Government of the People's Republic of Bangladesh, Dhaka, Bangladesh.

3. BBS (Bangladesh Bureau of Statistics), 2004. Statistical Yearbook for Bangladesh., Statistics Division, Ministry of Planning, Government of the People's Republic of Bangladesh, Dhaka, Bangladesh.

4. BBS (Bangladesh Bureau of Statistics), 2008. Statistical Yearbook for Bangladesh., Statistics Division, Ministry of Planning, Government of the People's Republic of Bangladesh, Dhaka, Bangladesh 
5. BBS (Bangladesh Bureau of Statistics), 2010. Statistical Yearbook for Bangladesh., Statistics Division, Ministry of Planning, Government of the People's Republic of Bangladesh, Dhaka, Bangladesh

6. BBS (Bangladesh Bureau of Statistics), 2012. Statistical Yearbook for Bangladesh, Statistics Division, Ministry of Planning, Government of the People's Republic of Bangladesh, Dhaka

7. Bose ML, A Ahmed, and M Hossain, 2009. The Role of Gender in Economic Activities with Special Reference to Women's Participation and Empowerment in Rural Bangladesh. Gender, Technology and Development, Vol. 13, No. 1, January-April.

8. Cain, Khanam and Nahar, 1979. "Class Patriarchy and the Structure of Women's Work in Rural Bangladesh". The Population Council, New York.

9. Chakma TK, 1995. A socio-economic study of women participation in crop and vegetable production activities in a selected area of Khagrachari Hill District. M.Sc. Ag. Econ. Thesis, Department of Agricultural Economics, Bangladesh Agricultural University, Mymensingh.

10. FAO, 2003. Gender, Key to sustainability and Food Security, Plan of Action: Gender and Development, FAO, Rome.

11. Farzana C, 2004. Impact of Seasonality on the time utilization Pattern of Rural women in Agricultural and other Activities. Journal of Maharashtra Agricultural Universities, 29: 62-64.

12. Fontana M and C Paciello, 2010. Gender Dimensions of Rural and Agricultural Employment: Differential pathways out of Poverty: A Global Perspective. In Gender imensions of Agricultural and Rural Employment: Differentiated Pathways out of Poverty. Rome: FAO/IFAD/ILO.

13. ILO, 2009. Gender Equality and Decent Work. Work Selected ILO Convensions and Recommendations Promoting Gender Equality.

14. Jaim WMH and ML Rahman, 1988. Participation of women and children in Agricultural activities- A macro level study in an area of Bangladesh. The Bangladesh Journal of Agricultural Economics, 11: 31-50, June. 